\title{
Magnitudes of Climate Variability and Changes over the Arid and Semi-Arid Lands of Kenya between 1961 and 2013 Period
}

\author{
Jully O. Ouma ${ }^{1,2 *}$, Luke 0. Olang ${ }^{3}$, Gilbert O. Ouma ${ }^{1,2}$, Christopher Oludhe ${ }^{1,2}$, Laban Ogallo ${ }^{1,2}$, \\ Guleid Artan ${ }^{2}$ \\ ${ }^{1}$ Department of Meteorology, University of Nairobi, Nairobi, Kenya \\ ${ }^{2}$ IGAD Climate Prediction and Applications Centre (ICPAC), Nairobi, Kenya \\ ${ }^{3}$ Department of Biosystem and Environmental Engineering, Technical University of Kenya, Nairobi, Kenya \\ Email: *jully.ouma@gmail.com
}

How to cite this paper: Ouma, J.O., Olang, L.O., Ouma, G.O., Oludhe, C., Ogallo, L. and Artan, G. (2018) Magnitudes of Climate Variability and Changes over the Arid and Semi-Arid Lands of Kenya between 1961 and 2013 Period. American Journal of Climate Change, 7, 27-39.

https://doi.org/10.4236/ajcc.2018.71004

Received: October 30, 2017

Accepted: February 11, 2018

Published: February 14, 2018

Copyright $\odot 2018$ by authors and Scientific Research Publishing Inc. This work is licensed under the Creative Commons Attribution International License (CC BY 4.0).

http://creativecommons.org/licenses/by/4.0/

c. (i) Open Access

\begin{abstract}
The magnitude and trend of temperature and rainfall extremes as indicators of climate variability and change were investigated in the Arid and Semi-Arid Lands (ASALs) of Kenya using in-situ measurements and gridded climate proxy datasets, and analysed using the Gaussian-Kernel analysis and the Mann-Kendall statistics. The results show that the maximum and minimum temperatures have been increasing, with warmer temperatures being experienced mostly at night time. The average change in the mean maximum and minimum seasonal surface air temperature for the region were $0.74^{\circ} \mathrm{C}$ and $0.60^{\circ} \mathrm{C}$, respectively between the $1961-1990$ and 1991-2013 periods. Decreasing but statistically insignificant trends in the seasonal rainfall were noted in the area, but with mixed patterns in variability. The March-April-May rainfall season indicated the highest decrease in the seasonal rainfall amounts. The southern parts of the region had a decreasing trend in rainfall that was greater than that of the northern areas. The results of this study are expected to support sustainable pastoralism system prevalent with the local communities in the ASALs.
\end{abstract}

\section{Keywords}

Arid and Semi-Arid Lands, Climate Variability and Change, Northern Kenya

\section{Introduction}

Variability and changes in extreme temperatures and rainfall patterns have been experienced in many parts of the world including Eastern Africa [1] [2] [3]. A 
recent Intergovernmental Panel for Climate Change (IPCC) assessment has indicated that the changes provide a key challenge to the current and future sustainability of the socio-economic systems, especially within the arid and semiarid regions [2] [4] [5]. In Kenya, over $80 \%$ of the country is classified as Arid and Semi-Arid Lands (ASALs), with most of these located in the northern parts of the county bordering Southern Ethiopia and Eastern Somalia. In the region, livestock agriculture is a key source of livelihood for the rural population, where about 75\% of the livestock in Kenya are found [6] [7] [8] [9].

Several studies have indicated that pastoralist agriculture in the ASALs of Kenya is increasingly becoming vulnerable to the effects of climate variability and change. Despite this, the sector still has poor economic development due to lack of appropriate adaptation strategies that targets the socio-economic practices of the rural population [10] [11] [12].

To support proper adaptation, there is need to assess the evidence of climate variability and change in the ASAL regions in order to provide estimates that can be used to forecast prospective changes in future. This will lead to an understanding of the historical and present magnitude of the changes, while providing an idea of how the change may affect related climate sensitive sectors important for policy support options. Generally in the ASALs of Kenya, few studies have attempted to quantify the magnitudes of climate change and variability to provide localised statistics for management decision making. Mureithi and Opiyo (2010) in their study of resource planning for Turkana and Pokot pastoralist regions under conditions of climate change and variability, did note that the mean annual temperature generally varied between $26^{\circ} \mathrm{C}$ and $38^{\circ} \mathrm{C}$. Omolo (2010) also reported that the annual mean temperature of the Turkana region ranges between $24^{\circ} \mathrm{C}$ and $38^{\circ} \mathrm{C}$. Due to data limitation, both of these studies largely focused on Turkana area using datasets obtained through local surveys and random sampling from the rural communities consequently, the authors recommended further studies across entire ASALs of the Northern Kenya using actual observation and proxy datasets.

Presently, several analytical methods have been proposed to assess possible changes in the magnitudes of temperature and rainfall. Rahmstorf and Coumou (2011) [39] used Monte Carlo simulations to quantify the effect of long-term trends of extreme warming events in the world. Though good results were obtained at the global scales, the evidence of the variability at localized scale was not clearly captured due to the coarse resolution of the global dataset used. Other studies [13] [14] [15] have used the Gaussian Kernel distribution method to locate the effect and evidence of climate change. These methods provide an opportunity at localised scales to assess the changing shape of the probability distribution with time and shift in the mean values. Considering the eminent data scarcity of the ASALs of Kenya, such methods were preferred in this study to investigate the magnitude of climate variability and change, with a view of providing localised climate change statistics. Besides, such a study will contribute to regional climate 
change adaptation and policy support options within the livestock sector as outlined in the country's economic strategic plan, the Kenya's vision 2030.

\section{Materials and Methods}

\subsection{Description of the Study Region}

Kenya is located between latitudes $5^{\circ} \mathrm{S}$ and $5^{\circ} \mathrm{N}$ and longitudes $34^{\circ} \mathrm{E}$ and $42^{\circ} \mathrm{E}$, covering an area of 58,037,000 $\mathrm{Ha}$ [16] with about $80 \%$ of the land classified ASALs. This work focussed on the northern area of the ASALs as a case study (Figure 1). The main water body in the region is Lake Turkana, which is the largest lake located in the ASALs [17]. Generally, the ASALs of Kenya are characterized by high temperatures coupled with low and poorly distributed rainfall.

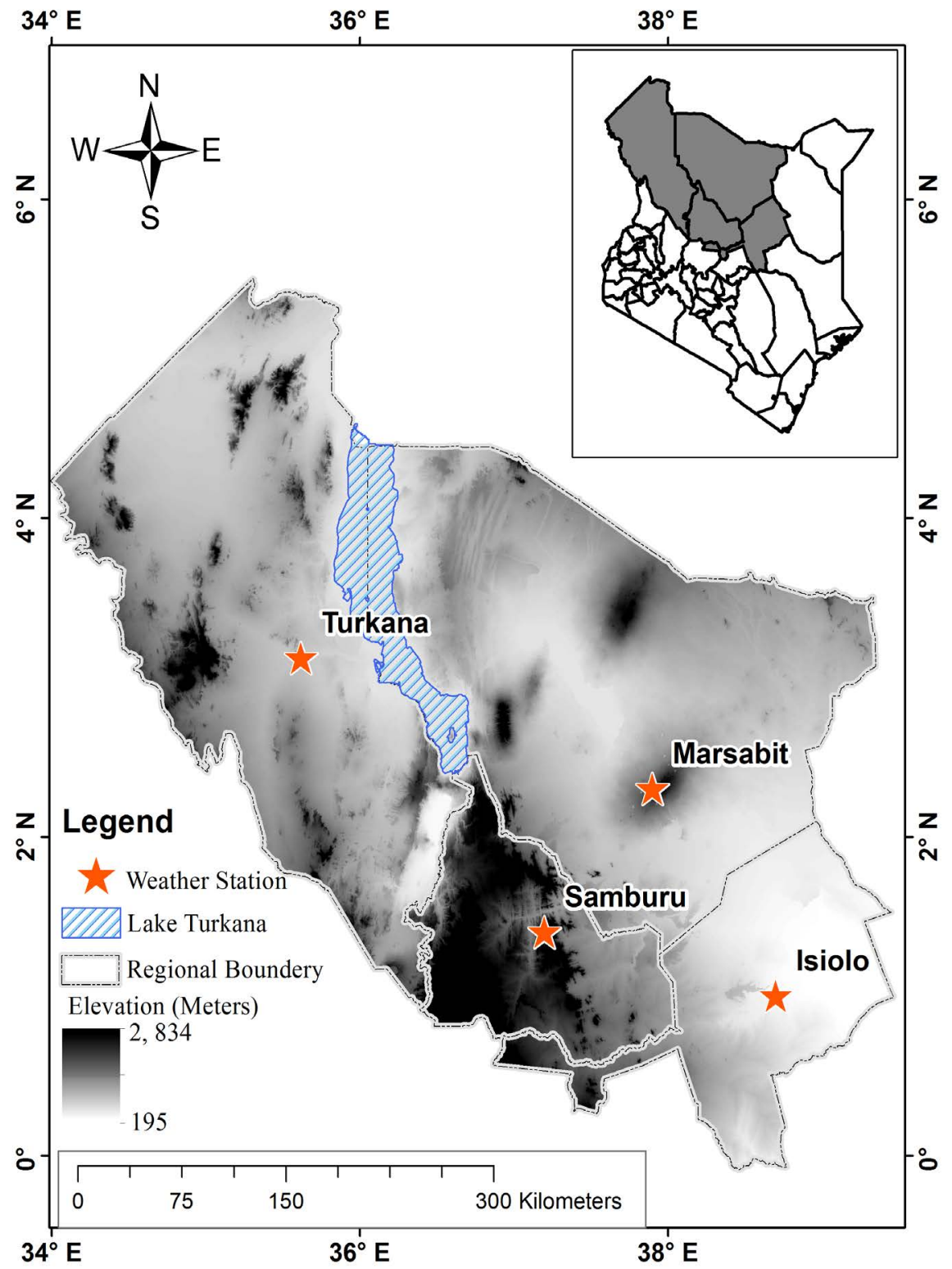

Figure 1. The studied arid and semi-arid lands in the northern part of Kenya (inset map). 
The mean annual rainfall in the region ranges between 200 and $600 \mathrm{~mm}$, with the region around Lake Turkana receiving less than $250 \mathrm{~mm}$ of rainfall per year [8] [18]. The highlands of the western part of the study area receive about 500 mm of rainfall annually [19] [20]. Marsabit region located to the east of Lake Turkana generally receives rainfall of up to $600 \mathrm{~mm}$ per year [18].

\subsection{Data Basis for the Study}

The data used in this study were monthly rainfall, and surface maximum and minimum air temperature. The in-situ data were obtained from the Kenya Meteorological Department (KMD) for the period 1961-2013. However, this dataset could not cover the entire study area as the available complete in-situ data was for two stations (Turkana and Marsabit). Due to absence of in-situ data for Samburu and Isiolo stations, the study used the $0.5^{\circ} \times 0.5^{\circ}$ gridded monthly University of East Anglia Climate Research Unit (CRU) datasets from 1961 to present [21] [22] [23] [24] for the entire study area. The available in-situ data from KMD was correlated with CRU data to assess the performance over the study area. A high correlation coefficient of $0.72(72 \%)$ was observed for the period 1961-2013. Authors over East Africa have used the CRU proxy dataset for rainfall and temperature analysis [22] [25] [26]. The annual rainfall and average temperature observed over the study area are shown in Table 1 below.

Generally, rainfall in the ASALs is bimodal, with March to May (MAM) experiencing the long rains and September to November (SON), the short rains; June to August (JJA) and December to February (DJF) are generally dry seasons [3] [27]. The dataset were divided into the DJF, MAM, JJA, and SON seasons for the non-overlapping WMO baseline period 1961-1990 and the climate change period 1991-2013 climatic periods. The data were then subjected to various trend analyses in order to delineate the temporal patterns of rainfall characteristics at specific locations as discussed in the following subsequent sections.

\section{Tools and Methods}

\subsection{Mann-Kendall Non-Parametric Trend Test}

The non-parametric Mann-Kendall trend test (Equation (1)), which has been widely used [3] [28] [29] [30] [31] [32], was applied to determine the trends in rainfall and surface air temperature.

Table 1. Station location for the four regions used in the study with their annual rainfall and annual mean temperature for the period 1961-2013 using the gridded data CRU.

\begin{tabular}{ccccc}
\hline Regions & $\begin{array}{c}\text { Latitude } \\
\text { (Degrees) }\end{array}$ & $\begin{array}{c}\text { Longitude } \\
\text { (Degrees) }\end{array}$ & $\begin{array}{c}\text { Annual Rainfall } \\
(\mathrm{mm})\end{array}$ & $\begin{array}{c}\text { Annual Average } \\
\text { Temperature }\left({ }^{\circ} \mathrm{C}\right)\end{array}$ \\
\hline Turkana & $3.07 \mathrm{~N}$ & $35.38 \mathrm{E}$ & 526.6 & 26.4 \\
Marsabit & $2.20 \mathrm{~N}$ & $37.95 \mathrm{E}$ & 498.5 & 25.0 \\
Samburu & $1.26 \mathrm{~N}$ & $37.01 \mathrm{E}$ & 670.1 & 23.2 \\
Isiolo & $1.01 \mathrm{~N}$ & $38.84 \mathrm{E}$ & 551.4 & 27.3 \\
\hline
\end{tabular}




$$
\operatorname{tau}=\sum_{i=1}^{n-1} \sum_{j=i+1}^{n} \operatorname{sgn}\left(x_{j}-x_{i}\right)
$$

In (1), tau gives the degree of the slope which can either be positive, zero or negative, $x_{j}$ are the sequential values of observations at given time and can be expressed as $\theta$, and $n$ is the length of the data set, and

$$
\operatorname{sgn}(\theta)=\left\{\begin{array}{c}
1 \text { if } \theta>0 \\
0 \text { if } \theta=0 \\
-1 \text { if } \theta<0
\end{array}\right.
$$

The test statistic tau gives a positive (negative) trend when the value of tau is positive (negative) and no trend when tau is zero. The level of significance used in this study was 0.05 , and the trends were considered significant when the $\mathrm{P}$-value was less than or equal to 0.05 .

\subsection{Gaussian Kernel Distribution}

The Gaussian Kernel density distribution, which includes the first four moments, i.e., the mean and variance, skewness, and kurtosis, was used to assess the changes in climate for the periods 1961-1990 and 1991-2013 (Equation (3)). Several studies have also used this approach to analyse the evidence of climate change [13] [14] [15] [33] [34] [35] [36].

$$
g_{y}(f s)=\sum_{t=1}^{T} \frac{1}{h^{N}} K\left(\frac{y_{t}-f s}{h}\right)
$$

In (3) $K$ is the Kernel, $h$ is a scaling factor (bandwidth), $N$ is the number of samples, $f s$ is the matrix of the lead-fields, $y_{t}$ is the measurement recorded at the time samples $t=1, \ldots, \mathrm{T}$ [13] [33] [37]. Generally, the Gaussian Kernel distribution provides the mean of each climatic period, variance, skewness and kurtosis. Using these moments, it was possible to distinguish changes in climate over the study area between the selected two climatic periods.

\section{Results and Discussion}

The results showed that temperatures have been increasing steadily over the ASAL region of Northern Kenya since 1961 at all locations considered with different magnitudes represented by tau (Table 2). The increasing significant trends for surface maximum and minimum air temperature ranged from 0.3 to 0.56 and from 0.14 to 0.64 , respectively, for the period 1961-2013 for different seasons at all locations. In Table 2, the Turkana region was observed to have the highest increasing trend in all the seasons for surface maximum and minimum air temperature while the Isiolo region on average had the lowest increasing trend. This increase in temperature may lead to reduced soil moisture content as temperature and soil moisture are inversely related [38] which in turn affects forage production, thus negatively affecting livestock farming, which is the main livelihood in the ASALs of Kenya. The observed changes and increase in temperatures over the study area agrees with the studies at a regional scale by Christensen et al. (2007), and Ngaina and Mutai (2013) who concluded that temperatures are increasing over the East Africa region. Annual rainfall, on the other 
Table 2. Trends in rainfall, maximum and minimum surface air temperature for DJF, MAM, JJA, and SON seasons for the period 1961 to 2013.

\begin{tabular}{cccccccc}
\hline & & \multicolumn{2}{c}{ Max. Temperature } & \multicolumn{2}{c}{ Min. Temperature } & \multicolumn{2}{c}{ Rainfall } \\
\cline { 3 - 8 } & Stations & tau & p-value & Tau & p-value & tau & p-value \\
\hline & Turkana & 0.544 & 0.00 & 0.370 & 0.00 & -0.041 & 0.67 \\
& Marsabit & 0.362 & 0.00 & 0.144 & 0.14 & 0.043 & 0.66 \\
& Samburu & 0.427 & 0.00 & 0.369 & 0.00 & 0.013 & 0.90 \\
& Isiolo & 0.245 & 0.01 & 0.225 & 0.02 & 0.139 & 0.14 \\
& Turkana & 0.486 & 0.00 & 0.497 & 0.00 & -0.059 & 0.54 \\
& Marsabit & 0.356 & 0.00 & 0.408 & 0.00 & -0.115 & 0.23 \\
& Samburu & 0.360 & 0.00 & 0.385 & 0.00 & -0.131 & 0.17 \\
& Isiolo & 0.315 & 0.00 & 0.344 & 0.00 & -0.096 & 0.32 \\
& Turkana & 0.556 & 0.00 & 0.600 & 0.00 & 0.053 & 0.58 \\
& Marsabit & 0.515 & 0.00 & 0.573 & 0.00 & 0.036 & 0.71 \\
& Samburu & 0.469 & 0.00 & 0.538 & 0.00 & 0.031 & 0.75 \\
& Isiolo & 0.301 & 0.00 & 0.383 & 0.00 & -0.014 & 0.90 \\
& Turkana & 0.556 & 0.00 & 0.644 & 0.00 & 0.092 & 0.33 \\
& Marsabit & 0.409 & 0.00 & 0.479 & 0.00 & -0.032 & 0.74 \\
& Samburu & 0.452 & 0.00 & 0.529 & 0.00 & -0.026 & 0.79 \\
& Isiolo & 0.320 & 0.00 & 0.361 & 0.00 & -0.054 & 0.58 \\
\hline & & & & & & &
\end{tabular}

hand, was observed to decrease in most parts of the ASALs of Kenya but with a statistically insignificant trend. The MAM and SON seasons showed a decreasing trend in rainfall at most locations while the DJF and JJA seasons indicated a slight positive trend at most locations (Table 2). These can be attributed to the MAM and SON rainfall crossing over to JJA and DJF seasons, respectively. The rainfall trends were not statistically significant in all the regions.

Figure 2 illustrates the observed shifts in the Gaussian kernel distribution for maximum surface air temperature for the Turkana, Marsabit, Samburu, and Isiolo regions in the JJA season. The shift in the distribution is a clear indication that climate has changed over the ASALs of Kenya. The dotted line representing the mean line of the periods and from the graph it shows a shift to the right indicating an increase in temperature. The spread of the distribution which indicates the variability in temperature fluctuates from one location to another (Figure 2). The same pattern was observed for minimum surface air temperature over the regions which indicated that the night temperatures have become warmer. A similar pattern was also observed for the DJF, MAM and SON seasons for both maximum and minimum temperatures.

The spatial analyses of seasonal rainfall over the study area showed that rainfall ranged between $30-180 \mathrm{~mm}, 110-500 \mathrm{~mm}, 0-300 \mathrm{~mm}$ and $110-380 \mathrm{~mm}$ in the DJF, MAM, JJA, and SON seasons, respectively. Previous studies have also indicated that the eastern side of Turkana region receives an annual rainfall of $200 \mathrm{~mm}$ while the western highlands receive over $500 \mathrm{~mm}$ [18] [19] [20]. Using 

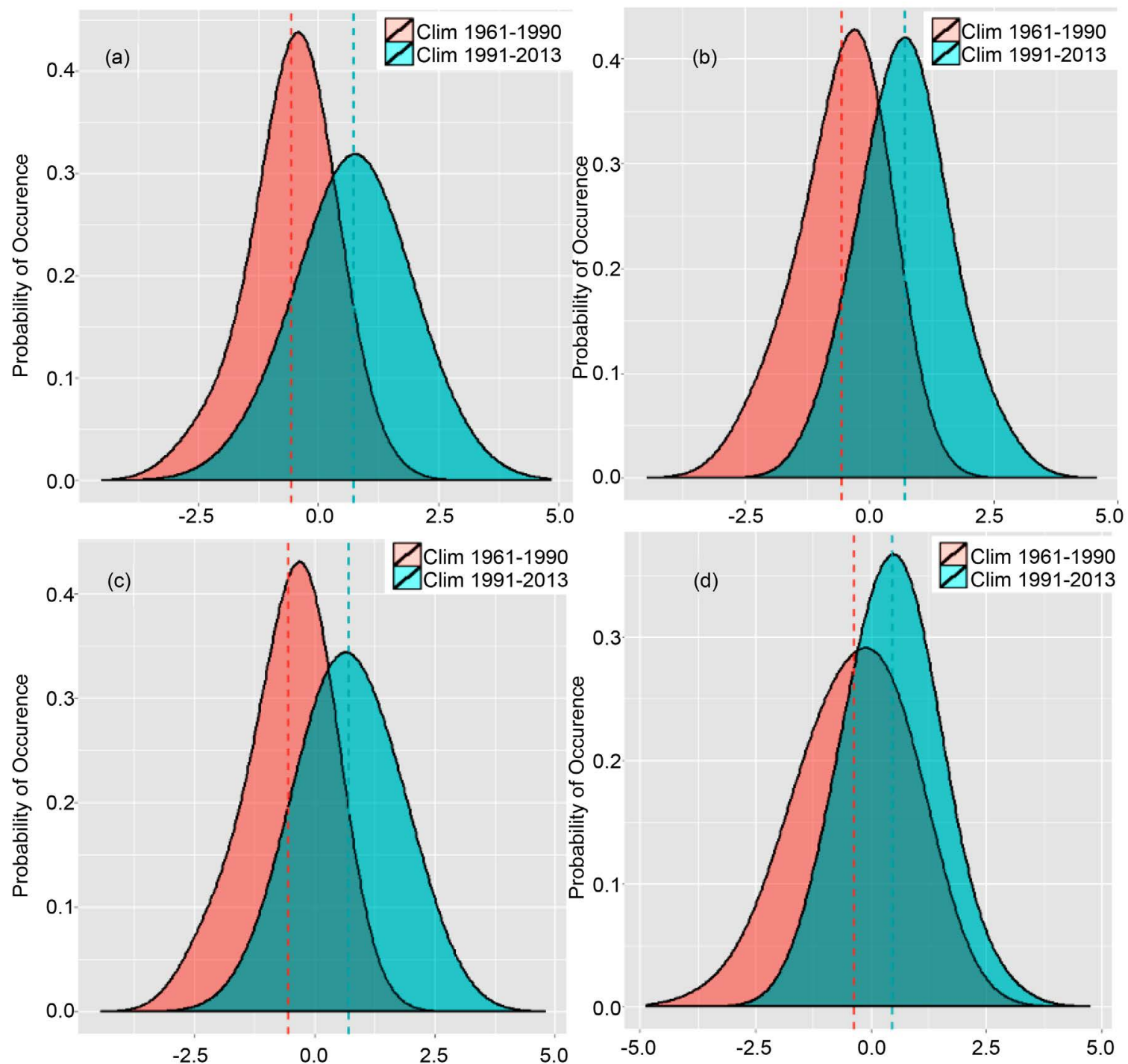

Figure 2. June-July-August distribution of maximum surface air temperature anomalies over (a) Turkana, (b) Marsabit, (c) Samburu, and (d) Isiolo Counties for different climatic periods, 1961-1990 and 1991-2013 using CRU data.

the non-overlapping climatic periods in Figure 3, it was noted that the mean of total MAM seasonal rainfall has decreased over the entire study area with more drought events than floods. The same observation was also made for the SON season. The decrease in seasonal total rainfall in these two seasons can be attributed to the late onset of seasonal rainfall over the ASALs. This late onset in MAM and SON could be the main cause of rainfall increase in JJA and DJF seasons over the ASALs.

\section{Mean and Variance in Temperature and Rainfall}

Change in the mean of maximum surface air temperature between the periods 1961-1990 and 1991-2013 ranged from $0.4^{\circ} \mathrm{C}$ to $1.18^{\circ} \mathrm{C}$ while that for minimum surface air temperature ranged between $0.18^{\circ} \mathrm{C}$ and $0.91^{\circ} \mathrm{C}$ for the four seasons (Table 3). The highest change in surface maximum air temperature $\left(1.18^{\circ} \mathrm{C}\right)$ was 

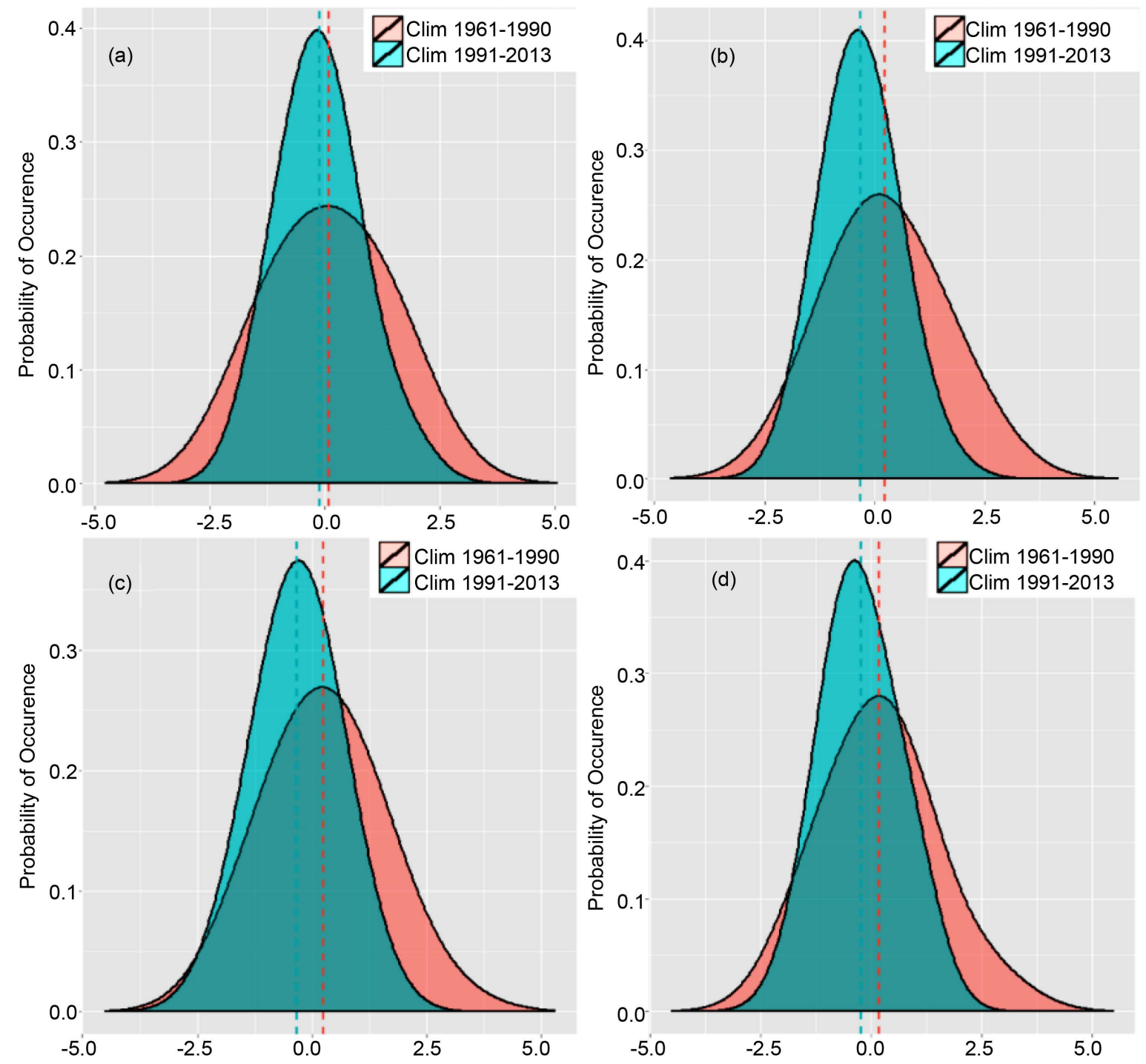

Figure 3. March-April-May distribution of rainfall anomalies over (a) Turkana, (b) Marsabit, (c) Samburu, and (d) Isiolo Counties for different climatic periods, 1961-1990 and 1991-2013 using CRU data.

observed over Turkana region in the DJF season while that of minimum temperature was observed in the SON season over Turkana region. The study also showed that the mean of annual surface air temperature increased by about $1.2^{\circ} \mathrm{C}$ in the period 1991-2013 as compared to 1961-1990.

The rainfall was observed to be high over the southern part of the study area (much of Samburu region) during the DJF, MAM, and SON seasons and low over the much of Turkana region in the north-western part of the study area (Table 3), which was attributed to the influence of orography over the study area. However, the rainfall in the JJA season was observed to be high over the western part of the study area due to the influence of the western highlands of the Turkana region. The observed variability in maximum and minimum temperature over the study area was nonhomogeneous with some regions indicating an increase in variability while others showed a decrease in variability (Table 4). 
Table 3. Mean of maximum and minimum surface air temperature and total rainfall for DJF, MAM, JJA, and SON seasons for the periods 1961-1990 and 1991-2013 based on CRU data.

\begin{tabular}{|c|c|c|c|c|c|c|c|c|c|c|}
\hline \multirow[b]{2}{*}{ Mean } & \multirow[b]{2}{*}{ Stations } & \multicolumn{3}{|c|}{ Max. Temperature $\left({ }^{\circ} \mathrm{C}\right)$} & \multicolumn{3}{|c|}{ Min. Temperature $\left({ }^{\circ} \mathrm{C}\right)$} & \multicolumn{3}{|c|}{ Rainfall (mm) } \\
\hline & & $\frac{\circ}{\frac{1}{1}}$ & $\frac{m}{\stackrel{n}{1}}$ & 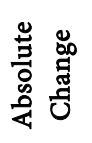 & $\begin{array}{l}\stackrel{\circ}{2} \\
\frac{1}{2} \\
\stackrel{-}{-1}\end{array}$ & $\begin{array}{l}m \\
\stackrel{n}{\circ} \\
\frac{1}{\sigma}\end{array}$ & 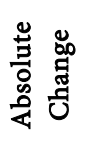 & $\frac{\$}{\frac{1}{1}}$ & $\frac{m}{\stackrel{n}{1}}$ & 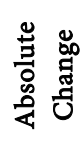 \\
\hline \multirow{4}{*}{ 䗆 } & Turkana & 33.86 & 35.04 & 1.18 & 18.95 & 19.58 & 0.63 & 47.75 & 42.86 & 4.89 \\
\hline & Marsabit & 32.05 & 32.74 & 0.69 & 19.04 & 19.22 & 0.18 & 80.07 & 77.63 & 2.44 \\
\hline & Samburu & 30.13 & 30.96 & 0.83 & 15.87 & 16.39 & 0.52 & 123.45 & 126.13 & 2.68 \\
\hline & Isiolo & 33.75 & 34.21 & 0.46 & 21.18 & 21.44 & 0.26 & 96.13 & 104.56 & 8.43 \\
\hline \multirow{4}{*}{$\sum_{\Sigma}^{\sum}$} & Turkana & 32.96 & 33.93 & 0.97 & 20.31 & 21.20 & 0.89 & 189.14 & 178.79 & 10.35 \\
\hline & Marsabit & 31.06 & 31.77 & 0.71 & 19.83 & 20.40 & 0.57 & 263.68 & 214.56 & 49.12 \\
\hline & Samburu & 30.41 & 31.11 & 0.70 & 17.09 & 17.72 & 0.63 & 368.97 & 303.46 & 65.51 \\
\hline & Isiolo & 33.85 & 34.46 & 0.61 & 22.34 & 22.87 & 0.53 & 263.87 & 224.32 & 39.55 \\
\hline \multirow{4}{*}{$\overleftrightarrow{\Xi}$} & Turkana & 30.66 & 31.62 & 0.96 & 19.38 & 20.27 & 0.89 & 171.77 & 185.80 & 14.03 \\
\hline & Marsabit & 28.93 & 29.62 & 0.69 & 18.01 & 18.70 & 0.69 & 26.59 & 27.64 & 1.05 \\
\hline & Samburu & 28.65 & 29.38 & 0.73 & 15.01 & 15.84 & 0.83 & 67.17 & 72.85 & 5.68 \\
\hline & Isiolo & 31.60 & 32.04 & 0.44 & 20.10 & 20.60 & 0.50 & 0.26 & 0.25 & 0.01 \\
\hline \multirow{4}{*}{ Zo } & Turkana & 32.30 & 33.32 & 1.02 & 19.49 & 20.40 & 0.91 & 118.15 & 118.27 & 0.12 \\
\hline & Marsabit & 30.26 & 30.96 & 0.70 & 19.14 & 19.70 & 0.56 & 153.15 & 146.09 & 7.06 \\
\hline & Samburu & 29.84 & 30.57 & 0.73 & 16.56 & 17.23 & 0.67 & 259.68 & 247.98 & 11.70 \\
\hline & Isiolo & 32.87 & 33.27 & 0.40 & 21.45 & 21.84 & 0.39 & 206.18 & 201.84 & 4.34 \\
\hline
\end{tabular}

Table 4. Variance of rainfall, maximum and minimum surface air temperature for DJF, MAM, JJA, and SON seasons for the periods 1961-1990 and 1991-2013 based on CRU data.

\begin{tabular}{|c|c|c|c|c|c|c|c|c|c|c|}
\hline \multirow[b]{2}{*}{ Variance } & \multirow[b]{2}{*}{ Stations } & \multicolumn{3}{|c|}{ Max. Temperature $\left({ }^{\circ} \mathrm{C}\right)$} & \multicolumn{3}{|c|}{ Min. Temperature $\left({ }^{\circ} \mathrm{C}\right)$} & \multicolumn{3}{|c|}{ Rainfall (mm) } \\
\hline & & $\frac{\circ}{2}$ & 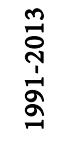 & 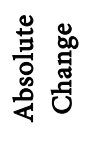 & $\begin{array}{l}\frac{8}{2} \\
\frac{1}{1} \\
2\end{array}$ & 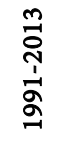 & 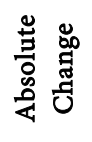 & $\begin{array}{l}\frac{2}{2} \\
\frac{1}{0} \\
2\end{array}$ & 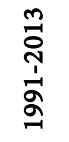 & 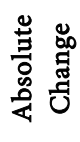 \\
\hline \multirow{4}{*}{ 岕 } & Turkana & 0.46 & 0.57 & 0.11 & 0.46 & 0.96 & 0.50 & 1.08 & 0.92 & 0.16 \\
\hline & Marsabit & 0.51 & 0.21 & 0.30 & 0.39 & 0.47 & 0.08 & 1.24 & 0.73 & 0.51 \\
\hline & Samburu & 0.53 & 0.39 & 0.14 & 0.29 & 0.52 & 0.23 & 1.11 & 0.90 & 0.21 \\
\hline & Isiolo & 0.75 & 0.23 & 0.52 & 0.32 & 0.22 & 0.10 & 1.23 & 0.73 & 0.50 \\
\hline \multirow{4}{*}{$\sum_{\sum}$} & Turkana & 0.55 & 0.31 & 0.24 & 0.43 & 0.42 & 0.01 & 1.29 & 0.64 & 0.65 \\
\hline & Marsabit & 0.52 & 0.14 & 0.38 & 0.22 & 0.16 & 0.06 & 1.27 & 0.50 & 0.77 \\
\hline & Samburu & 0.68 & 0.21 & 0.47 & 0.30 & 0.28 & 0.02 & 1.19 & 0.60 & 0.59 \\
\hline & Isiolo & 0.66 & 0.15 & 0.52 & 0.20 & 0.22 & 0.02 & 1.27 & 0.58 & 0.69 \\
\hline \multirow{4}{*}{$\overleftrightarrow{\Xi}$} & Turkana & 0.28 & 0.38 & 0.10 & 0.27 & 0.21 & 0.06 & 1.15 & 0.84 & 0.31 \\
\hline & Marsabit & 0.16 & 0.18 & 0.02 & 0.19 & 0.09 & 0.10 & 1.19 & 0.78 & 0.41 \\
\hline & Samburu & 0.19 & 0.23 & 0.04 & 0.19 & 0.13 & 0.06 & 1.12 & 0.86 & 0.26 \\
\hline & Isiolo & 0.28 & 0.19 & 0.09 & 0.20 & 0.14 & 0.06 & 1.11 & 0.89 & 0.22 \\
\hline \multirow{4}{*}{ ž } & Turkana & 0.50 & 0.35 & 0.15 & 0.27 & 0.34 & 0.07 & 1.38 & 0.54 & 0.84 \\
\hline & Marsabit & 0.40 & 0.22 & 0.18 & 0.17 & 0.15 & 0.02 & 1.24 & 0.72 & 0.52 \\
\hline & Samburu & 0.45 & 0.21 & 0.24 & 0.17 & 0.20 & 0.03 & 1.18 & 0.80 & 0.38 \\
\hline & Isiolo & 0.46 & 0.15 & 0.31 & 0.18 & 0.12 & 0.06 & 0.84 & 1.25 & 0.41 \\
\hline
\end{tabular}


The variability in rainfall has decreased at most locations in the study area in all the seasons, except for Isiolo which indicated an increase in variability during the SON rainfall season (Table 4).

\section{Conclusions}

The Mann-Kendall trend test, Gaussian Kernel distribution, and the method of moments were used to assess the climate variability and change in the ASAL regions of Kenya. Maximum and minimum temperatures depicted decreasing variability over most of the ASAL region but an increasing trend over all locations resulting to warmer night time temperatures. The increase in mean surface air temperature in the December-February season ranged between 0.21 and $1.5^{\circ} \mathrm{C}$, over the period considered. On average, the mean seasonal maximum and minimum temperature over the entire study region increased by $0.74^{\circ} \mathrm{C}$ and $0.60^{\circ} \mathrm{C}$, respectively. The mean annual temperature for the entire region ranged from $25^{\circ} \mathrm{C}$ to $34.8^{\circ} \mathrm{C}$. The values for the Turkana region have previously been reported as between $24^{\circ} \mathrm{C}$ and $38^{\circ} \mathrm{C}$ [19] [20]. The slight variation in these results is attributed to type of data used. The two previous studies [19] [20] used datasets obtained through local surveys and random sampling from the rural communities, while this study used CRU dataset which is a blend of satellite observation and in-situ (station) data.

The magnitude of rainfall over the ASALs study region of Kenya showed a decreasing trend in the recent past except for Isiolo. The baseline period of 1991-2013 was generally drier than the period 1961-1990. The southern sector depicted a greater decrease in rainfall than the northern sector. The MarchApril-May season had the highest but statistically insignificant decline in seasonal rainfall amounts. The University of East Anglia Climate Research Unit gridded observational datasets were well correlated to the observed rainfall data in regions without rainfall stations, which agrees with the work by Endris et al. (2013) and Omondi (2014).

This study provides critical climate information for purposes of regional planning and adaptation strategies in the ASALs to reduce vulnerability of pastoral and agro-pastoral livelihoods to increasing climate variability and changes.

\section{Acknowledgements}

The authors acknowledge the support of the University of Nairobi and the IGAD Climate Prediction and Applications Centre (ICPAC) for the sponsorship of this study. To the anonymous reviewers, many thanks for your constructive comments that contributed significantly towards shaping this work.

\section{References}

[1] Christensen, J.H., Hewitson, B., Busuioc, A., Chen, A., Gao, X., Held, R., Jones, R., Kolli, R.K., Kwon, W.K., Laprise, R. and Magaña R.V. (2007) Regional Climate Projections. Climate Change, The Physical Science Basis. Contribution of Working Group I to the Fourth Assessment Report of the Intergovernmental Panel on Cli- 
mate Change, University Press, Cambridge, 847-940.

[2] Flato, G., Marotzke, J., Abiodun, B., Braconnot, P., Chou, S.C., Collins, W.J., Cox, P., Driouech, F., Emori, S., Eyring, V. and Forest, C. (2013) Evaluation of Climate Models. Climate Change 2013: The Physical Science Basis. Contribution of Working Group I to the Fifth Assessment Report of the Intergovernmental Panel on Climate Change. Climate Change, 5, 741-866.

[3] Ngaina, J. and Mutai, B. (2013) Observational Evidence of Climate Change on Extreme Events over East Africa. Global Meteorology, 2, 2. https://doi.org/10.4081/gm.2013.e2

[4] Olang, L.O. (2009) Analyses of Land Cover Change Impact on Flood Events Using Remote Sensing (RS), GIS and Hydrological Models. A Case Study of the Nyando River Basin in Kenya. PhD Dissertation, University of Natural Resources and Applied Life Sciences, Vienna.

[5] Sheffield, J., Wood, E.F., Chaney, N., Guan, K., Sadri, S., Yuan, X., Olang, L., Amani, A., Ali, A. and Demuth, S. (2014) A Drought Monitoring and Forecasting System for Sub-Sahara African Water Resources and Food Security. Bulletin of the American Meteorological Society, 95, 862-882.

https://doi.org/10.1175/BAMS-D-12-00124.1

[6] Indeje, M., Semazzi, F.H. and Ogallo, L.J. (2000) ENSO Signals in East African Rainfall Seasons. International Journal of Climatology, 20, 19-46. https://doi.org/10.1002/(SICI)1097-0088(200001)20:1<19::AID-JOC449>3.0.CO;2-0

[7] FAO (2005) Livestock Sector Brief Kenya. http://www.fao.org/ag/againfo/resources/en/publications/sector_briefs/lsb_UGA.pdf

[8] Orindi, V., Nyong, A. and Herrero, M. (2007) Pastoral Livelihood Adaptation to Drought and Institutional Interventions in Kenya. https://cgspace.cgiar.org/handle/10568/2511

[9] PDNA (2012) Kenya Post-Disaster Needs Assessment (PDNA) 2008-2011 Drought. http://www.gfdrr.org/sites/gfdrr/files/Kenya_PDNA_Final.pdf

[10] Dutra, E., Giuseppe, F.D., Wetterhall, F. and Pappenberger, F. (2013) Seasonal Forecasts of Droughts in African Basins Using the Standardized Precipitation Index. Hydrology and Earth System Sciences, 17, 2359-2373. https://doi.org/10.5194/hess-17-2359-2013

[11] Djikeng, A., Rao, I.M., Njarui, D., Mutimura, M., Caradus, J., Ghimire, S.R., Johnson, L., Cardoso, J.A., Ahonsi, M. and Kelemu, S. (2014) Climate-Smart Brachiaria Grasses for Improving Livestock Production in East Africa. Tropical GrasslandsForrajes Tropicales, 2, 38-39. https://doi.org/10.17138/TGFT(2)38-39

[12] Assan, N. (2015) Focusing on Livestock Improvement Strategies That Enhance Adaptive and Coping Mechanisms in the Context of Climate Change in Southern Africa. Scientific Journal of Animal Science, 4, 72-80.

[13] Bessa, R.J., Miranda, V., Botterud, A., Wang, J. and Constantinescu, E.M. (2012) Time Adaptive Conditional Kernel Density Estimation for Wind Power Forecasting. IEEE Transactions on Sustainable Energy, 3, 660-669.

[14] Ogungbenro, S.B. and Morakinyo, T.E. (2014) Rainfall Distribution and Change Detection across Climatic Zones in Nigeria. Weather and Climate Extremes, 5, 1-6. https://doi.org/10.1016/j.wace.2014.10.002

[15] Chen, Y., Liu, F., Mei, S. and Ma, J. (2015) Toward Adaptive Robust State Estimation Based on MCC by Using the Generalized Gaussian Density as Kernel Functions. International Journal of Electrical Power and Energy Systems, 71, 297-304. https://doi.org/10.1016/j.ijepes.2015.03.011 
[16] FAO (2011) Kenyan Country Profile. http://www.fao.org/countryprofiles/index/en/?iso3=KENandpaia $=4$

[17] Notenbaert, A., Thornton, P., Herrero, M. and ILRI Nairobi (Kenya) (2007) Livestock Development and Climate Change in Turkana District, Kenya. ILRI Targeting and Innovation Discussion Paper, No. 7, ILRI, Nairobi, 47 p.

[18] FAO (2006) Country Pasture/Forage Resource Profile for Kenya. https://pdfs.semanticscholar.org/1d7b/3d82527bce586638645a32e68f9df501b759.pdf

[19] Omolo, N.A. (2010) Gender and Climate Change-Induced Conflict in Pastoral Communities: Case Study of Turkana in Northwestern Kenya. African Journal on Conflict Resolution, 10, 81-102.

[20] Mureithi, S.M. and Opiyo, F.E. (2010) Resource Use Planning under Climate Change: Experience from Turkana and Pokot Pastoralists of Northwestern Kenya. 2nd International Conference on Climate, Sustainability and Development in Semi-Arid Regions, Fortaleza, 16-20 August 2010, 2.

[21] Mitchell, T.D. and Jones, P.D. (2005) An Improved Method of Constructing a Database of Monthly Climate Observations and Associated High-Resolution Grids. International Journal of Climatology, 25, 693-712. https://doi.org/10.1002/joc.1181

[22] Omondi, P.A.O., Awange, J.L., Forootan, E., Ogallo, L.A., Barakiza, R., Girmaw, G.B., Fesseha, I., Kululetera, V., Kilembe, C., Mbati, M.M. and Kilavi, M. (2014) Changes in Temperature and Precipitation Extremes over the Greater Horn of Africa Region from 1961 to 2010. International Journal of Climatology, 34, 1262-1277. https://doi.org/10.1002/joc.3763

[23] Harris, I., Jones P.D., Osborn T.J. and Lister D.H. (2014) Updated High-Resolution Grids of Monthly Climatic Observations-The CRU TS3.10 Dataset. International Journal of Climatology, 34, 623-642. https://doi.org/10.1002/joc.3711

[24] CRU TS v.3.22. (2014) A Gridded Time Series Dataset. http://browse.ceda.ac.uk/browse/badc/cru/data/cru_ts/cru_ts_3.22/data/

[25] Sabiiti, G. (2008) Simulation of Climate Scenarios Using the PRECIS Regional Climate Model over the Lake Victoria Basin. Master's Thesis, University of Nairobi, Nairobi.

[26] Endris, H.S., Omondi, P., Jain, S., Lennard, C., Hewitson, B., Chang'a, L., Awange, J.L., Dosio, A., Ketiem, P., Nikulin, G. and Panitz, H.J. (2013) Assessment of the Performance of CORDEX Regional Climate Models in Simulating East African Rainfall. Journal of Climate, 26, 8453-8475. https://doi.org/10.1175/JCLI-D-12-00708.1

[27] Omeny, P.A., Ogallo, L., Okoola, R., Hendon, H. and Wheeler, M. (2006) East African Rainfall Variability Associated with the Madden-Julian Oscillation. Journal of Kenya Meteorological Society, 2, 105-114.

[28] Hipel, K.W. and McLeod, A.I. (1994) Time Series Modelling of Water Resources and Environmental Systems. Elsevier, Amsterdam. https://cgspace.cgiar.org/handle/10568/575

[29] Yue, S., Pilon, P. and Cavadias, G. (2002) Power of the Mann-Kendall and Spearman's Rho Tests for Detecting Monotonic Trends in Hydrological Series. Journal of Hydrology, 259, 254-271. https://doi.org/10.1016/S0022-1694(01)00594-7

[30] McLeod, A.I. (2005) Kendall Rank Correlation and Mann-Kendall Trend Test. $R$ Package “KendalP”. https://cran.r-project.org/web/packages/Kendall/

[31] Hamed K.H. (2008) Trend Detection in Hydrologic Data: The Mann-Kendall Trend Test under the Scaling Hypothesis. Journal of Hydrology, 349, 350-363. 
https://doi.org/10.1016/j.jhydrol.2007.11.009

[32] Orlowsky, B. (2015) Consistency, Homogeneity and Summary Statistics of Climatological Data. R Package "iki.dataclim". https://cran.r-project.org/web/packages/iki.dataclim/

[33] Mohseni, H.R., Kringelbach, M.L., Woolrich, M.W., Baker, A., Aziz, T.Z. and Probert-Smith, P. (2014) Non-Gaussian Probabilistic MEG Source Localisation Based on Kernel Density Estimation. NeuroImage, 87, 444-464. https://doi.org/10.1016/j.neuroimage.2013.09.012

[34] McCabe, P., Korb, O., Cole, J. and Taylor, R. (2014) Kernel Density Estimation of CSD Distributions-An Application to Knowledge Based Molecular Optimisation. Journal of Cheminformatics, 6, 10. https://doi.org/10.1186/1758-2946-6-S1-P10

[35] Chu, C.Y., Henderson, D.J. and Parmeter, C.F. (2015) Plug-In Bandwidth Selection for Kernel Density Estimation with Discrete Data. Econometrics, 3, 199-214. https://doi.org/10.3390/econometrics3020199

[36] Van Ackooij, W. and Minoux, M. (2015) A Characterization of the Subdifferential of Singular Gaussian Distribution Functions. Set-Valued and Variational Analysis, 23, 465-483. https://doi.org/10.1007/s11228-015-0317-8

[37] Terrell, G.R. and Scott, D.W. (1992) Variable Kernel Density Estimation. The Annals of Statistics, 20, 1236-1265. https://doi.org/10.1214/aos/1176348768

[38] Lakshmi, V., Jackson, T.J. and Zehrfuhs, D. (2003) Soil Moisture-Temperature Relationships: Results from Two Field Experiments. Hydrological Processes, 17, 3041 3057. https://doi.org/10.1002/hyp.1275

[39] Rahmstorf, S. and Coumou, D. (2011) Increase of Extreme Events in a Warming World. Proceedings of the National Academy of Sciences, 108, 17905-17909. https://doi.org/10.1073/pnas.1101766108 